Research Report No. 33/2012

\title{
The Aesthetics of Religious Freedom
}

Benjamin L. Berger

Osgoode Hall Law School of York University, bberger@osgoode.yorku.ca

Follow this and additional works at: http:/ / digitalcommons.osgoode.yorku.ca/clpe

\section{Recommended Citation}

Berger, Benjamin L., "The Aesthetics of Religious Freedom" (2012). Comparative Research in Law \& Political Economy. Research Paper No. 33/2012.

http://digitalcommons.osgoode.yorku.ca/clpe/14 


\title{
OSGOODE
}

\section{OSGOODE HALL LAW SCHOOL}

Comparative Research in Law \& Political Economy

RESEARCH PAPER SERIES

Research Paper No. 33/2012

\section{The Aesthetics of Religious Freedom}

\author{
Benjamin L. Berger
}

Editors:

Peer Zumbansen (Osgoode Hall Law School, Toronto, Director Comparative Research in Law and Political Economy)

John W. Cioffi (University of California at Riverside)

Leeanne Footman (Osgoode Hall Law School, Toronto, Production Editor)

Comparative Research in 


\title{
The Aesthetics of Religious Freedom
}

\author{
Benjamin L. Berger
}

The scope and nature of religious freedom is a matter of aesthetics. This is not to claim that all questions of religious establishment and religious liberty can be reduced solely to aesthetic considerations. Rather, this claim is intended to identify an under-examined and yet elemental component of what conditions and shapes religious freedom in contemporary liberal constitutional orders. The influence of aesthetics on religious freedom may not always be determinative but it will never be absent. Yet the role of aesthetics in structuring both the doctrine and lived realities of the constitutional protection of religion in modern societies has gone without critical comment in the growing literature on secularism and religious freedom in the modern rule of law. The purpose of this piece is to explore the extent to which aesthetic commitments influence the manner in which religion is imagined and dealt with by the law. Religious diversity, multiculturalism, tolerance, and accommodation are all subject, I will argue, to the force of law's aesthetics. My claim is that institutional responses to religious difference are predicated on aesthetic reactions, reactions that will anchor the terms on which religious communities will either find acceptance within the legal order or will find themselves in seemingly intractable conflict with the law.

Raising the issue of aesthetics is to gesture to a nest of possible topics. A substantial body of work has considered law and aesthetics from the more colloquial or conventional understanding of aesthetics as the study of the artistic or of judgments about the beautiful. ${ }^{1}$ Under the rubric of "aesthetics" others yet have considered the relationship between legal imagery or art and the authority of law. ${ }^{2}$ Indeed, we are currently faced with a number of questions involving the relationship between law and religion that seem to turn on aesthetics in this more conventional sense of "image" or "representation", including the French ban on "conspicuous religious symbols" or the Canadian debate over the niqab and law's desire to see the face of the witness.

Although important and interesting, these issues and analyses engage a very different, and less basic, sense of the aesthetic than this piece invokes. When one turns back

\footnotetext{
* Associate Professor, Osgoode Hall Law School, York University. Many thanks to John Borrows, Hamar Foster, and the participants in the Varieties of Religious Establishment workshop held at St. Thomas University in Fredericton, New Brunswick, in November 2010, for their valuable comments on earlier versions of this chapter. Thank you also to Hannah Askew and Jessica Gagne for their outstanding research assistance.

${ }^{1}$ Daniel J Boorstin, The Mysterious Science of the Law: An Essay on Blackstone's Commentaries (Gloucester: Peter Smith, 1973); Adam Geary, Law and Aesthetics (Oxford: Hart Publishing, 2001).

${ }^{2}$ Costas Douzinas \& Lynda Neal, Law and the Image: The Authority of Art and the Aesthetics of Law (Chicago: University of Chicago Press, 1999); Costas Douzinas, Shaun McVeigh \& Ronnie Warrington, "The Alta(E)Rs of Law: The Judgement of Legal Aesthetics" (1992) 9:4 Theory, Culture \& Society 93.
} 
to its etymological roots, ${ }^{3}$ the word "aesthetic" refers to the basic elements of sense or perception. This is the meaning of aesthetics that Kant used in his discussion of the transcendental aesthetic in The Critique of Pure Reason ${ }^{4}$ and it is precisely this aspect of Kant's thought that offers the conceptual vocabulary that frames this chapter. Famously, Kant argued that

In whatsoever mode, or by whatsoever means, our knowledge may relate to objects, it is at least quite clear that the only manner in which it immediately relates to them is by means of an intuition. To this as the indispensable groundwork, all thought points. ${ }^{5}$

Whatever conceptions or structures of thought might inform human reason and analysis, for Kant the starting point had to be the recognition that our sense of objects - phenomena are given to us in the frame of intuitions. Certain of those intuitions, Kant argued, were empirical in nature, arising as they did from our engagement with specific objects in the world. But even these sensations must come to us arranged in some form, subject to some structure of reception. And so something in our minds must pre-exist our engagement with and sensations of a given object, something capable of giving form and order to these experiences of phenomena:

And accordingly we find existing in the mind a priori, the pure form of sensuous intuitions in general, in which all the manifold content of the phenomenal world is arranged and viewed under certain relations. This pure form of sensibility I shall call pure intuition. ${ }^{6}$

As distinct from our empirical intuitions, which arise from our sensation of phenomena, pure intuition is that set of sensibilities that exist in advance of our perception of a given object, providing the basic framing of our reception of the world and, thereby, serving as what Kant called "principles of knowledge a priori". All thought would be grounded in these basic intuitions and the study of these most basic intuitions Kant called "transcendental aesthetic." The "aesthetic", here, is that basic frame or architecture of thought and reflection and Kant held that "there are two pure forms of sensuous intuition, as principles of knowledge a priori,

\footnotetext{
${ }^{3}$ Pierre Schlag makes a similar move in his piece, Pierre Schlag, "The Aesthetics of American Law" (2002) 115:4 Harvard Law Review 1047 at 150.

${ }^{4}$ Immanuel Kant, Critique of Pure Reason1781).

${ }^{5}$ Ibid at 23 .

${ }^{6}$ Ibid at 23

${ }^{7}$ Ibid at 24 .
} 
namely, space and time." ${ }^{\prime 8}$ For Kant, space and time - the essential aesthetic ingredients are the conditions under which all of our intuitions take place.

Although he took Kant in a cultural and symbolic turn, Ernst Cassirer nevertheless confirmed this aesthetic primacy of notions of time and space, arguing that "[s]pace and time are the framework in which all reality is concerned. We cannot," he argued, "conceive any real thing except under the conditions of space and time." Cassirer's project was developing a philosophy of human culture by exposing its "architectural structure", ${ }^{10}$ and an exploration of the formative aesthetic categories of space and time would prove indispensible: "To describe and analyze the specific character which space and time assume in human experience is one of the most appealing and important tasks of an anthropological philosophy".

If we understand the constitutional rule of law as one way of encountering the world, as one system of symbols and meanings that comprise "a way of being in the world" 12 - as, following Cassirer, a cultural form ${ }^{13}$ - then an analysis of the culture of law's rule should explore its aesthetics of time and space. ${ }^{14}$ No exploration of the culture of law's rule can dispense with an exploration of the shape of these basic frames for perception. In many respects one comes to the study of religion far more accepting of the claim that understanding a given religious culture will depend at some basic and indispensible level on wrestling with its framing intuitions about space and time. Yet as awkward as such questions might feel in the academic traditions of the study of law, they are no less central. And when one is specifically concerned with the cross-cultural encounter between the constitutional rule of law and diverse religious cultures, ${ }^{15}$ I suggest that these questions are particularly salient.

If intuitions frame our encounter with phenomena, and the basic form of intuition is the transcendental aesthetics, law's encounter with religion and the resulting concepts and structures of thought about religious freedom will be conditioned by its basic intuitions - its

\footnotetext{
${ }^{8}$ Ibid at 24.

${ }^{9}$ Ernst Cassirer, An Essay on Man: An Introduction to a Philosophy of Human Culture (New Haven and London: Yale University Press, 1944) at 42.

${ }^{10}$ Ibid at 36 .

${ }^{11}$ Ibid at 42

${ }^{12}$ Paul W. Kahn, The Cultural Study of Law: Reconstructing Legal Scholarship (Chicago and London: University of Chicago Press, 1999) at 36.

${ }^{13}$ See also Benjamin L. Berger, "Law's Religion: Rendering Culture" (2007) 45:2 Osgoode Hall L.J. 277; Desmond Manderson, Songs without Music: Aesthetic Dimensions of Law and Justice (Berkeley: University of California Press, 2000) at 201: "Law is a cultural medium of epxressisve form, through which senses and symbols are combined, communicated, and interpreted."

${ }^{14}$ Paul Kahn has provided an account of Law's Time and Law's Space in The Cultural Study of Law. Many of his insights, particularly from the architectural components of his analysis (as opposed to his genealogy of law's time and space), will inform this piece. The focus of this chapter, however, is on the implications of such conceptions on our understanding of religious freedom.

${ }^{15}$ See Benjamin L. Berger, "The Cultural Limits of Legal Tolerance" (2008) 21:2 Can. J. L. \& Jur. 245.
} 
unthought commitments - about time and space. Without at all diminishing the importance of the conventionally analyzed sites of friction between law and religion - the particular demands of public reason, the hidden normative content of liberalism, the meaning of the "secular", etc. - exploring the framing structures of legal thought and analysis seems essential to understanding the modern interaction between law and religion. In a volume fundamentally interested in the manner in which religion is understood in contemporary legal frameworks, this chapter asks about the role of law's aesthetics in shaping religious freedom. Beneath the doctrine, subtending the jurisprudence, a priori assumptions about space and time have, I will argue, a formative impact on legal reactions to religious difference.

Using Kant's reflections on transcendental aesthetics as a touchstone for a piece that is centrally concerned with cultural and religious pluralism may be counter-intuitive. His reflections on spatial and temporal intuitions were in service of identifying universal structures of human perception. To speak about varieties of framing intuitions about space and time operative in different cultural formations is perhaps, in this sense, in tension with Kant's original project. ${ }^{16}$ His concept of the transcendental aesthetic nevertheless affords a uniquely convenient and illuminating vocabulary for exploring the framing intuitions that ground legal analysis; and more than this, the hope is to draw out and exploit this very tension between the universalism of the original concept and the pluralist uses to which it is being put in this chapter, thereby methodologically underscoring another theme in this chapter: that the close study of cultural and religious difference within the law frequently involves the realization that what we imagine to be universal, immutable, or natural is in fact surprisingly and challengingly plural.

In what follows I will offer initial reflections about the peculiar intuitions or framing assumptions about space, and then time, that inform the culture of law's rule, identifying ways in which each might have implications for the shape and nature of religious freedom and establishment. In each section I will offer examples drawn from the Canadian law of religious freedom that suggests the potency of these basic intuitions and, with it, the potential importance of a study of the aesthetics of religious freedom.

\section{Space and the Aesthetics of Religious Freedom}

They thought they could go back to find the same marked squirrels nesting in the walnut trees

\footnotetext{
${ }^{16}$ I am aware of elements in the philosophical literature on Kant that suggests a more pluralist reading of his ethics. See, e.g., Thomas E. Hill, "Kantian Pluralism" (1992) 102:4 Ethics 743 and Dermot Moran, "Hilary Putnam and Immanuel Kant: Two 'Internal Realists'?" (2000) 123:1 Synthese 65, in which Moran describes Hilary Putnam's account of the "glimmerings of 'conceptual relativity' and 'pluralism"” (83) in Kant's ethical thought.
} 
and that there would be some work

to do, something useful

and hard, and that they might please

their own need to be doing.

You know what they found. They found

themselves standing in your yard

awed by the gladiolus

and the absence of something

they knew. This had been free land,

they said, but now it was yours

who went in to call the law. ${ }^{17}$

The City of Outremont, a vibrant part of Montreal, is home to a large orthodox Jewish population. On Shabbat, the weekly day of rest that is also holiest day of the year, a piece of Rabbinic wisdom rings in the ears of Orthodox Jews - "The Jews did not preserve the Shabbas; the Shabbas preserved the Jews." It is a day with deep temporal significance, marking off sacred time from the everyday business of the week, but the key admonition against work on Shabbat has profound implications for how orthodox Jews move in the world. One can draw this sense of Shabbat being both a temporal and spatial event from the word used for observing Shabbat - one is shomer Shabbas. "Shomer" comes from the root "to guard." One guards Shabbat.

The home is the sacred space of Shabbat. The injunction against work includes a prohibition on carrying items outside one's home. In a modern urban life, this prohibition poses certain serious limitations - one would be prevented from pushing a stroller, from carrying medication, or even from bringing keys outside the home in order to lock the door when one goes to synagogue on Shabbas or another Jewish holiday.

The eruv has served as the solution to this halachic (legal) conundrum. The eruv is a barely visible wire erected in Jewish communities to symbolically extend the special space of the home across lanes and sidewalks, common areas, and public spaces, turning them into a metaphorical extension of the home. ${ }^{18}$ The space bounded by the eruv is transformed into part of one's home, allowing movement through the community on the holy days. The word eruv means "to mix or join"; the eruv mixes the home and the public, breaking down the distinction in service of sacrality and in recognition of the day of rest, a day that brings into each week the memory of the end of God's creation of the world.

\footnotetext{
${ }^{17}$ Philip Levine, "Possession" in Not this pig; poems (Middletown, Connecticut: Wesleyan University Press, 1968) at p 31.

${ }^{18}$ For a description of the technical features of the eruv, see Roger Stump, Geography of Religion: Faith, Place and Space (Maryland: Rowman \& Littlefield Publishers, 2008), at 3.
} 
The City of Outremont began dismantling the system of eruvin in 2000, objecting to their presence across city streets and public spaces. The City took these steps pursuant to its "duty to maintain the public domain accessible to all residents of Outremont on the same basis and without distinction." 19 One argument made by the parties supporting the removal of the eruvin was that "the erection of eruvin involuntarily place non-members of the Orthodox Jewish faith within what amounts to a religious enclave with which they do not wish to be associated." 20 To allow the eruvin "would inevitably create what amounts to an officially recognized religious territory". ${ }^{21}$ A group of petitioners from the Jewish community sought relief from the Quebec Superior Court in 2001, claiming that the actions of the City interfered with their constitutionally protected right of religious freedom. The Court found that the City had a supervening public authority to regulate the erection of the eruv but that this should be done in a way that gave reasonable room for the members of the religious community to observe their private commitments.

Some years before, also in Montreal, a number of Jewish members of a condominium association, the Syndicat Northcrest erected a temporary booth, called a succah, for the eight-day festival of Succot. Jewish law and tradition requires that one eat meals and dwell as much as possible in the succah for the duration of this holiday. The very basic structures, covered with foliage but open enough that one can see the stars at night, are reminders of the fragile homes in which Israelites lived as they made that most crucial of territorial journeys over the span of 40 years, from slavery in Egypt, to their homes in Eretz Israel, the land of Israel. The succah is a compendious reminder of this journey, of the space of freedom, of the sacrality of home, and of the promise of a homeland.

A number of residents of the Syndicat Northcrest built their succahs on their balconies, considered common space under the condominium bylaws. These bylaws prohibited alterations to the external appearance of the building and the erection of structures in the communal spaces of the condominium. A negotiation between the Jewish residents and the building management ensued, with a compromise found for many of the residents - a single communal succah would be built on the grounds of the condominium. Certain of the residents could not agree to this, however, convinced as they were that they were each under an obligation to have a personal succah and unsatisfied with a common succah that would require them to carry items through common space during the holiday in order to use this structure. Despite having signed the condominium bylaws when they purchased their units, Moïse Amselem and three other Jewish residents insisted on the religious freedom to build their own succahs on their balconies. The case eventually found its way to the Supreme Court of Canada, where the Court held that, properly circumscribed,

\footnotetext{
${ }^{19}$ Rosenberg v. Outremont (City), [2001] R.J.Q. 1556 (S.C.) at para. 14.

${ }^{20}$ Ibid at para. 18.

${ }^{21}$ Ibid.
} 
the applicants' private religious beliefs could be accommodated within the regime of collective property rights. ${ }^{22}$

When such events come before the bar of the law, to what spatial aesthetic are they subject? The question matters because, as Kant and Cassirer suggest, space is one of those framing intuitions that conditions the manner in which a culture will receive and respond to phenomena. The developing critical geographical literature has similarly emphasized the role of spatial understandings and metaphors as foundational aspects of how both individuals and cultures interpret and understand both their worlds and themselves. ${ }^{23}$ One can "see through" spatial metaphors and territorial conceptions, understanding them "as implicating and being implicated in ways of thinking, acting, and being in the world - ways of worldmaking informed by beliefs, desires and culturally and historically contingent ways of knowing." ${ }^{24}$ In this sense, these conceptions of space "are significant cultural artifacts of a rather special kind." 25 As Delaney writes, "[o]ne might go so far as to say that a cultural formation or social order is unintelligible without reference... to how it is territorially expressed." 26 As a particularly salient modern cultural formation, one should expect to find the liberal rule of law informed by and expressed in a sense of space and territoriality. And as a component of the legal way of "world-making," the imprint of this spatial logic will also be seen in the law's treatment of religion and claims of religious freedom, an imprint that I am describing as one aspect of the aesthetics of religious freedom.

"Morality," Kahn writes, "may be without borders, but law's rule begins only with the imagination of jurisdiction." 27 Jurisdiction is the guiding metaphor for law's understanding of space, serving as the conceptual means of "mapping" authorities within the legal world. As Valverde puts it, "the governance of legal governance is the work of jurisdiction." 28 Although the concept of "jurisdiction" is not solely spatial - organizing, as it does, authority over objects, relationships, and topics - its function in organizing and interpreting territorial or spatial relations is what interests me here. Jurisdiction is "a way of

${ }^{22}$ Syndicat Northcrest v. Amselem, [2004] 2 S.C.R. 551.

${ }^{23}$ David Delaney, Territory: A Short Introduction (Oxford: Blackwell, 2005). See also Nicholas Blomley, Law, Space and the Geographies of Power (New York: Guilford Press, 1994); Wesley Pue, "Wrestling with Law: (Geographical) Specificity V. (Legal) Abstraction" (1990) 11 Urban Geography 566; Kai Raustiala, "The Geography of Justice" (2005) 73 Fordham L. Rev. 2501.

${ }^{24}$ Delaney, supra note 23 at 12.

${ }^{25}$ Ibid.

${ }^{26}$ Ibid at 10 .

${ }^{27}$ Kahn, supra note 12 at 55.

${ }^{28}$ Mariana Valverde, "Jurisdiction and Scale: Legal 'Technicalities' as Resources for Theory" (2009) 18 Social \& Legal Studies 139 at 141. 
speaking and understanding the social world" ${ }^{29}$ one that does so by charting the boundaries of the legitimate exercise of authority. The experience of the social space of the law is one of moving within multiple domains of authority. Space matters to the law precisely inasmuch as it is called upon to answer the question: "who has authority or jurisdiction here?"

Some articulations of this jurisdictional way of organizing space closely mirror the cartographic. National and international borders are emphatically and obviously a matter of territory and the reach of political authority. These borders are not just (or even principally) physical; rather, they are aspects of the legal imagination that make territory as much an ethical as a geographical matter. Cases concerning the extraterritorial reach of even our most fundamental legal principles - in Canada, the extraterritorial impact of the Charter ${ }^{30}$ - are such fraught questions precisely because the legal system is not solely a moral system but also a jurisdictionally-ordered social world. The same play of space and authority can be seen in Canada's internal federal organization. The constitution (in all senses of the word) of the political community in Canada is based on the jurisdictional arrangement of competing legal authorities. The great spatial question of federalism is whether a matter is intra vires a province or a matter of federal regulation. Again, the lines on the political map of Canada are symbolic markers for the boundaries of legitimate authority. This is not to say that these lines aren't real; it is, instead, to emphasize that, as Ford puts it, "they are constantly being made real" ${ }^{11}$ through the range of practices of authority that take place within the culture of law's rule.

Yet some the most influential aspects of the spatial intuitions of the law are not so literal, cartographic, and largely writ. Indeed, as Delaney observes, "the micro-territories of everyday life may be more significant - or at least more noticeable, than the macro-territories of global politics"32 and the legal imagination has much to say about these "microterritories." Like all other territorial imaginations, legal space "is as much a metaphysical phenomenon as a material one", ${ }^{33}$ implicating basic ontological questions that help to constitute political and social relations within the culture of law. Perhaps the most potent example of this ontological and social work done by legal mappings of space is the law of property, one of the building blocks of western legal culture. "Within the ongoing practice of law's rule, any particular space appears first of all as property." ${ }^{34}$ Property law is precisely the framing of space into competing authorities. It involves the legal parcelling of authority over space and objects in space. Whether one has a fee simple interest in land or merely a leasehold is a legal distinction about space that shapes one's rights and entitlements within

${ }^{29}$ Richard T. Ford, "Law's Territory (a History of Jurisdiction)" (1999) 97 Mich. L. Rev. 843 at

855.

${ }^{30}$ See, e.g., R. v. Hape, 2007 SCC 26, [2007] 2 S.C.R. 292; Canada (Justice) v. Khadr, [2008] 2 S.C.R. 125

${ }^{31}$ Ford, supra note 29 at 856.

${ }^{32}$ Delaney, supra note 23 at 5.

${ }^{33}$ Delaney, supra note 23 at 12.

${ }^{34} \mathrm{Kahn}$, supra note 12 at 63. 
that sphere and, with this, one's social relations with other subjects. To interpret and negotiate space through the legal idea of property involves internalizing a particular range of power relations and distinctive ways of imagining the subject's relationship to the world and to other subjects; this is one respect in which the law does not merely act upon the world but, rather, "makes the world, helping to constitute the understandings and beliefs that make the world unfold this way, rather than that way," providing "hegemonic categories through which social life is ordered". ${ }^{35}$ As scholars of Indigenous legal traditions have suggested, cultural understandings of space that differ from those found in the western legal tradition can engender very different social relations and political formations. ${ }^{36}$ The jurisdictions of everyday life created through the legal metaphysics of property are an important aspect of the way in which law, as a cultural formation, uses spatial and territorial conceptions to constitute a social and political world.

Within that social and political world constituted by the spatial intuitions of legal culture, the division of the world into private and public domains is of utmost importance. This distinction is, of course, "[o]ne of the most consequential of categorical boundaries relating to the spatial order of property", ${ }^{37}$ dividing the world into two spheres of ownership: public and private. Much ink has been spilled on the centrality of this division to the liberal rule of law and some of it has explored the way in which this manner of dividing up the world distorts or fails to reflect the experience of those subject to law's rule. Yet law's fealty to a manageable and real distinction between the private and public is deep, an artefact of the contemporary constitutional rule of law's relationship to liberal political culture; as Blomley puts it, this distinction is "one of the crucial axes of liberal legalism". ${ }^{38}$ The personal or private is protected space, the space in which interest and preference can guide conduct and, most crucially, the space over which the state has the weakest claim to authority. The public, by contrast, is the domain of state power and (concomitantly) governed by the demands of public reason over personal interest or preference. The influence of this ontological distinction is felt throughout the culture of law's rule, shaping constitutional principles as much as it does property relations. One need go no further than the law of search and seizure to find a pristine expression of this way of carving up space; the state has a claim of authority over that which is left in public space or available for public observation entirely distinct from the privacy enjoyed in one's personal space - be it the hyper-private space of

\footnotetext{
${ }^{35}$ Nicholas Blomley, "Flowers in the Bathtub: Boundary Crossings at the Public-Private Divide" (2005) 36 Geoforum 281 at 282.

${ }^{36}$ See, e.g., Paul Nadasdy, "'Property' and Aboriginal Land Claims in the Canadian Subarctic: Some Theoretical Considerations" (2002) 104 American Anthropologist 247; James (Sákéj) Youngblood Henderson, "Postcolonial Indigenous Legal Consciousness" (2002) 1 Indigenous Law Journal 1; John Borrows, Recovering Canada: The Resurgence of Indigenous Law (Toronto; Buffalo: University of Toronto Press, 2002), esp. ch. 2, "Living Between Water and Rocks: The Environment, First Nations, and Democracy".

${ }^{37}$ Blomley, supra note 35 at 283.

${ }^{38}$ Blomley, supra note 35 at 283.
} 
the body or the hallowed territory of the home. ${ }^{39}$ Even when it comes to the exercise of fundamental rights and freedoms not all space is treated equally. The ambit of freedom of expression will differ vastly as between one's home, a public school, a private school, a park, a legislature, and an airport. These differences can all be traced to varying conceptions of the nature and locus of authority exercised in each of these spaces. Otherwise put, when the expressive event appears before the law, it appears subject to and within a preconception of space in which the salient and instinctive question is "who has what legitimate authority in this space?" The accretion of these private/public distinctions does more than just formal legal work; it provides "a pervasive vocabulary through which the socio-spatial world is rendered intelligible." 40 The resulting complex maps of private and public spaces, and their political and social implications, are an important part of the "micro-territories of everyday life" ${ }^{41}$ lived under the rule of law.

The argument of this piece is that the peculiar spatial intuitions in culture of the rule of law imprint on the management and analysis of issues of religious freedom. In this way it is possible to speak of a spatial aesthetics of religious freedom. In supporting this assertion, one temptation would be simply to invoke broad claims about the nature of space in religion and to show an inherent conflict between "religious ways" of imagining space and what I have thus far described about the law. One might, for example, invoke Eliade and claim that, for religion, space is understood in terms of the sacred and the profane, ${ }^{42}$ a meaningful way of dividing up the world that is simply missed if law approaches space as a matter of jurisdictional authority. It is no doubt true that many religions will find the sacred/profane division more true to their sense of movement through space. Where this is so, there might be a fundamental misunderstanding when law and religion meet on a given issue that involves questions of space. But this will not be true of all religions and such sweeping claims on the religious side are not, ultimately, terribly edifying.

My purpose is instead to suggest that that law of religious freedom has an aesthetic component that - quite apart from any particular doctrinal development or argument about the just in a given case - shapes the way in which such issues will be discussed and draws out particular terms as the salient terms for discussing freedom of religion. One ignores law's intuitions about space and jurisdiction at one's peril when advancing or analyzing claims of religious freedom made within a liberal culture of law's rule. Consider the cases explored at the outset of this section. The eruv was a problem for the law (and for the City of Outremont) because it sought to destabilize the border between the very private space of the

${ }^{39}$ See, e.g., R. v. Feeney, [1997] 2 S.C.R. 13, on the powers of the police to enter into a home; $R . v$. Patrick, [2009] 1 S.C.R. 579, on search, seizure and privacy rights on the borders between the home and public space.

${ }^{40}$ Blomley, supra note 35 at 284.

${ }^{41}$ Delaney, supra note 23 at 5.

${ }^{42}$ Mircea Eliade, Sacred and the Profane; the Nature of Religion (New York: Harcourt, Brace \& World, Inc., 1959). 
home and public spaces subject to public authority. In disrupting this border, the eruv also challenged the liberal commitment to confine religion to the private sphere, by symbolizing a spilling-over of private religion into public spaces. In her assessment of debates about the eruv in one London neighbourhood, Davina Cooper traces community hostility to the fact that the eruv "flaunted minority beliefs, practices and loyalties in a way that provocatively disregarded the liberal public/private divide." ${ }^{43}$ In transgressing the private/public border the eruv not only symbolically privatized public space, it "was seen... as also transgressing the divide by bringing inappropriate expressions of religious faith into the public domain." 44 The eruv "mixed" or "joined" the public and the private and, in this sense, was "an affront to ontological ordering principles". ${ }^{45}$ Within the range of distinctive religious beliefs and practices within this community, the eruv became a contested site precisely because it came into conflict with the law's orienting spatial intuitions. This is the aesthetics of religious freedom at play. In this case, resolving the religious freedom question would require clarifying and redrawing the lines between private and public, the realm of government authority and that of religious expression. The limit of a court's ability to reconcile a religious practice within legal space is one boundary of religious freedom.

Amselem, the case regarding the erection of a succah on a condominium balcony discussed above, ${ }^{46}$ demonstrates a similar dynamic. Quite simply, the matter would not have been of constitutional or legal moment were it not for the transgression of law's spatial aesthetics. Had Mr. Amselem enjoyed a fee simple property interest in his balcony, the matter would not appear as a question of religious freedom - there would have been no legal issue because Mr. Amslem's religious expression would have conformed to the spatial categories imagined by the constitutional rule of law. As a purely private expression, there would, in short, be no issue of religious freedom. The fact that this space had a somewhat undefined public quality is what lent the erection of the succah spatial relevance for the law, creating a constitutional issue. As with the eruv, the matter would turn on the Court's ability to reconcile public (or "collective") authority over this space with private interests; the case was ultimately about the management of spatial authority.

The case of Chamberlain v. Surrey School District No. $36^{47}$ is a final example of the imprint of these spatial framings on matters of religious freedom. The case involved a school board's decision, based on religious objections of parents in the community, to prohibit the use of three books depicting same-sex parented families for use in a Kindergarten/Grade One curriculum. The Supreme Court of Canada quashed this decision on the grounds that the School Board had failed to comply with the admonition in the legislation that all public

${ }^{43}$ Davina Cooper, Governing out of Order: Space, Law and the Politics of Belonging (London and New York: Rivers Oram Press, 1998) at 141.

${ }^{44}$ Cooper, supra note 43 at 130.

${ }^{45}$ Blomley, supra note 35 at 284.

${ }^{46}$ Supra, note 22.

${ }^{47}$ [2002] 4 S.C.R. 710. 
schools must be administered on "strictly secular and non-sectarian principles." 48 This decision can be fruitfully analyzed as a case about the concept of the secular and the demands of public reason. ${ }^{49}$ Yet one might well understand the case in somewhat different terms: that prior to either of these questions, the issue engaged a spatial intuition suffusing the doctrines of religious freedom.

Recall that Kant's interest in the transcendental aesthetics arose from the proposition that, prior to the development of further conceptions and propositions about phenomena, we had to receive or perceive these phenomena in an organizing structure. Time and space were the constituent elements of this structure. How, then, were the events in Chamberlain received by the law? These phenomena appeared to the law within the grid of competing authorities that shapes its spatial intuitions. At the core of the question of religious freedom raised by this case was the potent spatial fact that the events at issue were concerned with what happened in a public school. Had the books been suggested for use in a family's home, it would not appear as a legal event. Had the books been banned for use in a religious school, the doctrinal shape of the questions asked about religious freedom would have been manifestly different. This spatial distinction might not have mattered one whit to the religiously motivated participants in the discussion. Indeed, the tensions and passions provoked by this case may well have been inflamed by the mismatch between the way in which space mattered for the law and its relevance - or lack thereof - for those arguing that the books ought to be banned. Yet the spatial reception of these events - the aesthetics of religious freedom - set the frame of relevance and the terms for debate for this case.

\section{Time and the Aesthetics of Religious Freedom}

Time present and time past

Are both perhaps present in time future,

And time future contained in time past.

If all time is eternally present

All time is unredeemable. ${ }^{50}$

In 1763 the military hostilities between the British and French in what would later become Canada ceased with the signing of the Treaty of Paris. That treaty guaranteed the right of Roman Catholics in French Canada to carry on the practice of their religion. The Quebec Act of 1774, another crucial legal step in the development of the Canadian state, included similar provisions providing special protections and rights for the Roman Catholic Church. With Confederation in 1867, the modern Canadian state took form. The nation's

${ }^{48}$ School Act, R.S.B.C. 1996, c. 412, s. 76.

${ }^{49}$ See, e.g., Berger, supra note 13.

13.

${ }^{50}$ T.S. Eliot, "Burnt Norton" in Four Quartets (San Diego: Harcourt Brace Jovanovich 1971) at p. 
first constitution, the British North America Act, provided for the basic structures of government in Canada, defining the legislative, executive, and judicial powers, and instituted the particular brand of Canadian federalism with the division of legislative authority between the federal government and the provinces. Also included in the BNA Act (which would later be renamed the Constitution Act, 1867) was s. 93, a provision that gave authority to the provinces to legislate in respect of education. Yet this provision also carried forward the tradition of affording legally distinct status to religious education, reflecting the history of Protestant and Catholic minorities in French and English Canada, respectively, by protecting the rights and privileges of Protestant and Catholic minority schools.

In the mid-1980s the Ontario government sought to introduce a Bill providing for full funding of Roman Catholic separate high schools in Ontario. Despite the recent introduction of the Charter of Rights and Freedoms, the Bill did not extend similar funding or protection to denominational schools of other traditions. The constitutionality of this bill was put to the courts and one of the questions posed was whether the privileging of Roman Catholic schools was consistent with Charter protections of freedom of religion, which also prohibited state endorsement of religion, ${ }^{51}$ and the equality of treatment on grounds of religion. The Supreme Court of Canada discussed the nature and import of s. 93 of the Constitution Act, 1867, describing it as "part of a solemn pact resulting from the bargaining which made Confederation possible". ${ }^{52}$ The Court explained that

The protection of minority religious rights was a major preoccupation during the negotiations leading to Confederation because of the perceived danger of leaving the religious minorities in both Canada East and Canada West at the mercy of overwhelming majorities. ${ }^{53}$

In spite of the apparent conflict between such specific protection of a given religion's educational interests over those of others and the seeming awkwardness of holding this set of privileges together with the recently-affirmed Charter commitment to the equal treatment of religious groups, Justice Wilson, writing for a majority of the Court, held that this privileging of Roman Catholic education was immune from Charter scrutiny. Section 93, "which represented a fundamental part of the Confederation compromise" ${ }^{44}$ was not subject to the claims of freedom of religion.

This matter came back before the Supreme Court when a group of Jewish parents and a group of non-Catholic Christian parents sought a declaration that the failure to provide funding for Jewish and other Christian schools directly offended their s. 15(1) equality rights and freedom of religion, guaranteed by s. 2(a) of the Charter. Rather than

${ }^{51}$ R. v. Big M. Drug Mart, [1985] 1 S.C.R. 295.

${ }^{52}$ Reference Re Bill 30, [1987] 1 S.C.R. 1148 at 1173.

${ }^{53}$ Ibid at 1173 .

${ }^{54}$ Ibid at 1197-98. 
seeking to declare the funding of Roman Catholic Schools in Ontario unconstitutional, these parents sought the expansion of the funding regime - equal funding of their schools, the litigants argued, would protect their religious freedom in the same manner as Roman Catholic education protected Catholicism in the Province. The majority of the Court confirmed that s. 93 of the Constitution Act, 1867, served "to entrench constitutionally a special status for such classes of persons, granting them rights which are denied to others." 55 Yet when attention shifted to whether this offended the guarantee of freedom of religion, the Court again answered with an emphatic "no." "Without this 'solemn pact', this 'cardinal term' of Union, there would have been no Confederation," J56 Justice Iacobucci reasoned. "As a child born of historical exigency, s. 93 does not represent a guarantee of fundamental freedoms" 57 but, rather, was "the product of an historical compromise which was a crucial step along the road leading to Confederation." ${ }^{58}$ This status immunized it from the logic of freedom of religion; s. 2(a) simply did not apply.

While this case was being decided in Canada, Mr. Arieh Hollis Waldman, the father of two Jewish children enrolled in a private day school in Ontario, brought a similar claim before the U.N. Human Rights Committee. ${ }^{59}$ He argued that Ontario's policy of funding separate Roman Catholic Schools violated religious freedom and equality guarantees found in the International Covenant on Civil and Political Rights. The tribunal took account of the reasoning in the Bill C-30 case and the Adler decision, noting the special constitutional status of Roman Catholic education reflected in s. 93 of the Constitution Act, 1867. Yet it reasoned that "the fact that a distinction is enshrined in the Constitution does not render it reasonable and objective." 60

In the instant case, the distinction was made in 1867 to protect the Roman Catholics in Ontario. The material before the Committee does not show that members of the Roman Catholic community or any identifiable section of that community are now in a disadvantaged position compared to those members of the Jewish Community that wish to secure the education of their children in religious schools. Accordingly, the Committee rejects the State party's argument that the preferential treatment of Roman Catholic schools is nondiscriminatory because of its Constitutional obligation. ${ }^{61}$

The Human Rights Committee of the United Nations found Canada in violation of Article 26 of the International Covenant on Civil and Political Rights.

\footnotetext{
${ }^{55}$ Adler v. Ontario, [1996] 3 S.C.R. 609 at para. 25.

${ }^{56}$ Ibid at para. 29.

${ }^{57}$ Ibid at para. 30.

${ }^{58}$ Ibid at para. 29.

${ }^{59}$ Wadman v. Canada, HCROR, $76^{\text {th }}$ Sess, Annex, Communication No 694/1996 (1996).

${ }^{60}$ Ibid at para. 10.4 .

${ }^{61} \mathrm{Ibid}$.
} 
Kant privileged time in his transcendental aesthetics, stating that "[i]n it alone is all reality of phenomena possible." ${ }^{62}$ "Time," wrote Kant, "is the formal condition a priori of all phenomena whatsoever." ${ }^{3}$ If time is an a priori intuition that frames and gives form and order to all that is perceived, all sensation of or reflection on phenomena, can anything be said about the way in which distinctive framings of time condition the way that phenomena are understood and dealt with in the law? In particular, are there any ways in which such framings might shape the management of issues of religious freedom and the limits of legal tolerations? To identify such characteristics of time and temporality within the law would suggest another aspect of what we might call the aesthetics of religious freedom. In what follows I want to gesture towards certain potential features of this temporal aesthetic.

One way that temporality may come into the picture to shape and structure issues of religious freedom is at points of substantial divergence between religious conceptions of time and secular legal understandings. To be sure, religion and the law may have fundamentally different framings of the relevance of time, a mismatch that can produce miscommunications that afflict the law of religious freedom. In those cases one sees very clearly the import of accounting for a tacit temporal aesthetic in the law of religious freedom. In such cases, the limits of religious accommodation may be traceable in certain instances to a basic aesthetic dissonance. Consider the case of $A .(C)$. The case concerned an almost 15 year old girl suffering from Crohn's disease. ${ }^{64}$ Although her medical advice was that she was in life-saving need of a blood transfusion, as a devout Jehovah's Witness, she had signed an advance directive expressing her wish not to have such transfusions. The Manitoba legislation presumed competence for those 16 years or older and provided that no medical procedure could be undertaken against these older children's wishes unless this presumption was rebutted. A.C. was assessed and all accepted that she was legally competent - she was, in essence, a mature minor. Yet as a child under the age of 16, the legislation vested the treatment decision in a judge who was to balance a range of factors, ultimately issuing the order that comported with the best interests of the child. A.C. challenged the legislation on the basis that, as a competent minor who had expressed her wish to follow the dictates of her religion, the legislative scheme violated a number of her rights, including her right to freedom of religion.

The majority of the Court held that the legislation was constitutionally valid but ruled that her religious views ought to be given weight in the analysis of what is "in the best interests of the child" - the governing standard under the legislation. Justice Binnie,

\footnotetext{
${ }^{62}$ Kant, supra note 4 at 26.

${ }^{63}$ Ibid at 27.

${ }^{64}$ A.C. v. Manitoba (Director of Child and Family Services), [2009] 2 S.C.R. 181.
} 
dissenting, would have found the legislation unconstitutional on the basis that, as a mature minor, she had the sole authority to make such decisions. Justice Binnie's judgment is a model of perspicuity and modesty in the law of religious freedom, noting as he did that "[i]ndividuals who do not subscribe to the beliefs of Jehovah's Witnesses find it difficult to understand their objection to the potentially lifesaving effects of a blood transfusion." 65 Nevertheless, he concluded as follows:

The Charter is not just about the freedom to make what most members of society would regard as the wise and correct choice. If that were the case, the Charter would be superfluous. The Charter, A.C. argues, gives her the freedom - in this case religious freedom - to refuse forced medical treatment, even where her life or death hangs in the balance. ${ }^{66}$

Even with the greater constitutional margin that he affords for A.C.'s religious views, Justice Binnie's decision discloses something important - indeed, indispensible about the aesthetics of religious freedom. For both the majority and the dissent, the argument was about autonomy in the present and the impact of past authority. Despite their different conclusions, both decisions work within the temporal frame of the law, including the law of religious freedom. What is never on the table - what could never be on the table in matters of religious freedom - is the way that time framed A.C.'s experiences and her perception of her world. Her decision was made in the grip of a teleological sense that put the eternal welfare of her soul in the balance. Yet her eschatological aesthetic, that which informed the exercise of the autonomy that the Court fixed upon, could not be understood within the constitutional rule of law. Such sharp dissonances between religious and legal conceptions of time demonstrate one way in which religious freedom takes place within law's aesthetic instincts. However, I want to explore a more subtle way in which the distinctive temporality of legal culture influences the shape of religious freedom and, indeed, the range of secularisms that one finds in various communities.

Legal time - time as worked with within the constitutional rule of law - is a compendious reception of all of those moments in the life of the community bound by law that might serve as authority for the present. Kahn identifies the "historicity of law" as "its single most prominent feature" ${ }^{67}$ but he specifies the nature of this historicity: "Law's rule carries forward a past that makes a meaningful claim upon us." ${ }^{\prime 6}$ The student of the common law will find this feature in the basic principle of stare decisis as the building block

\footnotetext{
${ }^{65}$ Ibid at para. 191.

${ }^{66}$ Ibid at para. 163.

${ }^{67}$ Kahn, supra note 12 at 43.

${ }^{68}$ Ibid at 45.
} 
of the legal rule: the starting point for legal authority is fidelity to the past. ${ }^{69}$ As Kahn astutely observes, "[l] egal arugments do not begin by asking about 'the best outcome, all things considered.' They begin from a commitment to the past." ${ }^{0}$ This durable commitment to the past as the starting point for legal reasoning imprints itself on how law understands and interprets the social world. Constitutions express this relationship between time and the rule of law, with the formative documents and events that express both the is and the ought of a community at one point in history carrying forward to make claims upon us in the present. ${ }^{71}$ To the extent that it makes a meaningful claim upon us today, this past both communicates and constitutes political identity.

The most striking feature of law's time is its synchronicity. Like an individual's life story, the historical narrative that frames law's perception and reception of all events is the entirety of its past. "At any given moment, the law appears as the sum total of all that has been done and not yet undone." 72 The past remains present in its claims of legal authority, producing "a curious kind of temporal flatness in the relationship of legal tests and resources to each other." ${ }^{\text {"3 }}$ This "temporal flatness" inheres in the possibility that any legal event, any legal decision, may appear as influential in a given contemporary moment. As Martin Krygier observes, "the past of law...is not simply part of its history; it is an authoritative part of its present." "We don't know at any given point whether the best or most relevant authority on the rule of law will be a case decided in $2007^{75}$ or one decided in $1959 .{ }^{76}$ Both reflect moments in the legal life of the community and, despite the half century separating them, neither is of greater or lesser authority. Except in the most Whiggish of views, the law is not on an arc of progressive discovery, nor is it sequenced, with the past falling away into historical fact, making room for the authority of the present. This is what I mean by law's time as a compendious reception of all of those moments in the life of the community bound by law that might serve as authority for the present.

Appreciating law's time in this fashion raises an intriguing issue: can it even be said that law possesses a sense of "history"? Considering the nature of history as a symbolic form in human life, Cassirer observed that, before it could be said that historical consciousness had

${ }^{69}$ For the centrality of tradition to the rule of law, see also Anthony Kronman, "Law as Precedent" (1990) 99 Yale L.J. 1029.

${ }^{70}$ Kahn, supra note 12 at 43. See also Paul W. Kahn, The Reign of Law: Marbury V. Madison and the Construction of America (New Haven and London: Yale University Press, 1997) at 19. ("A critical element in our belief in the rule of law is that the future of the political order should be the same as its past. Law's rule is an exercise in the maintenance of political meanings already achieved. It links the future to the past....To abandon the problem of interpretation of meanings already present in the legal order, and to ask only how we can best order the future, is to abandon the rule of law.").

${ }^{71}$ See Hanna Fenichel Pitkin, "The Idea of a Constitution" (1987) 37 J. Legal Educ. 167.

${ }^{72}$ Kahn, supra note 12 at 43.

${ }^{73}$ Ibid at 51.

${ }^{74}$ Martin Krygier, "Law as Tradition" (1986) 5 Law and Philosophy 237 at 245.

${ }^{75}$ British Columbia (Attorney General) v. Christie, [2007] 1 S.C.R. 873.

${ }^{76}$ Roncarelli v. Duplessis, [1959] S.C.R. 121. 
truly taken up residence in human culture, myth was the prevailing view of time. "In myth," Cassirer wrote, "we find the first attempts to ascertain a chronological order of things and events, to give a cosmology and a genealogy of gods and men." that this cosmology and genealogy is not properly "history", and his explanation reflects provocatively on my description of law's time.

Cassirer distinguishes mythical time from historical time insofar as, in the former, " $t \mathrm{t}]$ he past, present, and future are still tied up together; they form an undifferentiated unity and an indiscriminate whole.... From the point of view of the mythical consciousness the past has never passed away; it is always here and now." " Historical consciousness, by contrast, is diachronic; for the historian, "facts belong to the past and the past is gone forever." 79 In this light, law's synchronic time appears to be a kind of mythical time, rather than a brand of historical time. The authoritative imminence of time past is part of a mythical vision in service of constructing a coherent national political story through law. Perhaps in this observation we find some account for the troubling ham-fistedness evinced by law when forced to deal with redress for historical injustice or, in Canada, claims to Indigenous title. Despite professed attempts to take account of historical truth, the law always meets these compelling cases and claims in thrall to a mythic sense of time - the myth of the community as constituted by law - into which it awkwardly seeks to digest the facts of history. The U.S. Supreme Court's reasoning in an early $19^{\text {th }}$ century Indigenous land rights case is exemplary:

However extravagant the pretension of converting the discovery of an inhabited country into conquest may appear, if the principle has been asserted in the first instance, and afterwards sustained; if a country has been acquired and held under it; if the property of the great mass of the community originates in it, it becomes the law of the land, and cannot be questioned. ${ }^{80}$

Whatever we learn about promises made and broken in the political history of the country, the law is insistent on a story whose moral is its own legitimacy.

${ }^{77}$ Cassirer, supra note 9 at 173.

${ }^{78}$ Ibid at 173.

${ }^{79}$ Ibid at 174

${ }^{80}$ Johnson \& Graham's Lessee v. M'Intosh, 21 U.S. (8 Wheat.) 543, 591, as cited in Eric Dannenmaier, "Beyond Indigenous Property Rights: Exploring the Emergence of a Distinctive Connection Doctrine" (2008) 86 Washington University L. Rev. 53. Dannenmaier also points to the 1992 Australian High Court decision in Mabo v. Queensland, in which the tension between the facts of history and what must be assumed for the purposes of legal authority/sovereignty is clear on the face of the judgment. See also Kent McNeil, "The Vulnerability of Indigenous Land Rights in Australia and Canada" (2004) 42 Osgoode Hall L.J. 217. 
The range of secularisms and varieties of religious establishment that one finds in modern western traditions are constituted in part by the force of these mythic stories carried through the authority of law. With this tethering of authority and history, law's time shapes the frame into which issues of religious and cultural difference are received, molding the sense of what is natural, possible, or unthinkable as a matter of religious freedom. One sees the imprint of this approach to temporality very clearly in the religious education cases with which I began this section. Claims of religious freedom had to be disposed of within the mythic time of law, in which the purchase of a "solemn pact" made in 1867, and its historical antecedents, was dispositive in a case heard in 1996, and despite the introduction of a Charter of Rights and Freedoms. This legal event - the challenge to the Roman Catholic School funding scheme - came to the courts already conditioned by the mythic time defining the Canadian community under its rule of law. The law of religious freedom could not be addressed outside of the frame of this temporal aesthetic, one in which the interreligious compact reached in the $18^{\text {th }}$ and $19^{\text {th }}$ centuries had as much authoritative purchase as the claims of religious equality in the modern secular state. When the matter was freed from this temporal/mythic frame, when the matter was brought before the UN Committee on Human Rights in the Waldman case, the analysis and result were both manifestly different. This is, perhaps, one way of understanding the claim that international law does not seem to be "law" in a conventional sense. Law works by appealing to resources within the unfolding story of a particular community wrestling with justice issues over time. Without an "us" upon which past authority calls in a meaningful way, without a compendious mythical story of community, international law loses this feature of legal reasoning, appearing more aspirational than legal. In Waldman the past authorities were not present in the same way, present as part of a temporal identity, and so the Committee could state that "the fact that a distinction is enshrined in the Constitution does not render it reasonable and objective." Needs a citation. True, but prior to the question of reasonableness and objectivity is the question of the aesthetics of religious freedom: the shaping of the boundaries of religious freedom in light of the history of a given community. There is an aesthetic intuition that informs religious freedom, imprinting on the varieties of religious establishment, of secularism, and of doctrines of religious freedom.

\section{Conclusion: The Indispensible Aesthetic Question}

In this chapter I have explored the idea that time and space are two intuitions of the culture of law's rule that sit at the foundation of the law of religious freedom. Appreciation for these aesthetic instincts is clearly not sufficient for understanding the legal response to deep religious difference. There is an important structure built on top of these, and other, basic and tacit commitments, a structure of concepts, doctrines, rules and provisions that combine to produce a textured law of religious freedom. But these frames, these aesthetic conditions, are never absent. Analysis of the variety of forms of secularism, of religious freedom, and of religious establishment - or even reflection on a given claim of religious 
freedom - will be impoverished if regard is not given to these conditioning intuitions in the culture of law's rule.

While seeking to expose the temporal and spatial components underwriting law's approach to religious freedom, I have gestured to ways in which these intuitive structures might be filled with different content in a variety of national contexts. Pursuing this line of inquiry may give traction to work exploring the range of ways that religious diversity and religious freedom appear in various societies around the world.

With respect to the spatial, one can begin to see how, within the larger brush strokes that I have described, the local particulars of the way in which the complex map of authority is laid over legal space will affect doctrines of religious freedom. In Canada, I invoked the role of federalism as an important experience in this division of authority; this genealogy of spatial authority in Canada points to certain resources for thinking about managing conflicting claims of authority. The same is true of the Canadian experience of engagement with the Aboriginal peoples on this land, an experience in which competing sovereignties and the notion of treaty have played important roles. And so, claims about managing religious diversity both drawing from and appealing to the spatial aesthetics of Canadian law begin to emerge. We might find federalist concepts, including the hyper-legal concept of jurisdiction, offered as a resource for managing religious difference, ${ }^{81}$ or a concept of treaty constitutionalism developed as an approach to speaking justly about cultural difference. ${ }^{82}$

Temporally, one might intuit a difference between revolutionary and evolutionary cultures of the constitutional rule of law. As Kahn shows in his work, the moment of revolution - the resetting of the legal time frame to begin again - has a profound impact on the content of law's mythic time, even its basic structure. As we use genealogy to fill this structure we see how a similarly revolutionary constitution in which that moment of fissure had religious dimensions will set the "downstream" terms of religious freedom, as they have in France. The evolutionary constitutional culture in Canada brings a host of compacts and compromises forward to shape religious freedom and religious establishment quite differently, as we have seen. It is only with sensitivity to the basic temporal aesthetic of law's rule - with the particular hold that the community's mythic past has on what is just and right today - that the source and durability of these differences comes into clear view.

When we ask what shape religious diversity under the rule of law will take in various societies or when we ask about how a given claim of religious freedom will be perceived and received in a given polity, it will never be enough to gesture broadly to the aesthetic foundations of law's rule. The inquiry will always have to be more specific, more finegrained. If, however, one takes law to be a cultural form, one way of seeing and making sense of the world, then attention to these broad and basic facets of legal perception will

\footnotetext{
${ }^{81}$ Ayelet Shachar, Multicultural Jurisdictions: Cultural Differences and Women's Rights (Cambridge: Cambridge University Press, 2001).

82 James Tully, Strange Multiplicity: Constitutionalism in an Age of Diversity (Cambridge: Cambridge University Press, 1995).
} 
never be dispensable. To ask about the varieties of religious establishment - indeed, to wonder about the possibilities open to us for responding to religious diversity through the law - requires first recognizing, and then wrestling with, the temporal and spatial aesthetics of religious freedom. 